BARBARA JANKOWIAK

Uniwersytet im. Adama Mickiewicza

$w$ Poznaniu

EWA WOJTYNKIEWICZ

Uniwersytet Kazimierza Wielkiego

w Bydgoszczy

\title{
KSZTAŁTOWANIE SIĘ TOŻSAMOŚCI W OKRESIE ADOLESCENCJI A PODEJMOWANIE ZACHOWAŃ RYZYKOWNYCH W OBSZARZE UŻYWANIA ALKOHOLU PRZEZ MLODZIEŻ
}

\begin{abstract}
AвSTRAct. Jankowiak Barbara, Wojtynkiewicz Ewa, Ksztattowanie się tożsamości w okresie adolescencji a podejmowanie zachowań ryzykownych w obszarze używania alkoholu przez młodzież [Personality Moulding During Adolescence and Taking Risk Behaviours in the Context of Using Alcohol by Adolescents]. Studia Edukacyjne nr 48, 2018, Poznań 2018, pp. 169-185. Adam Mickiewicz University Press. ISSN 1233-6688. DOI: 10.14746/se.2018.48.11

The adolescence period is a time in which appear some significant adjustments concerning one's identity. Adolescents, both males and females, have to undertake new forms of behaviour and experiment in order to determine their own place in the society and to find the answer to the question 'who am I?'. Risk behaviours, including using alcohol by young people during adolescence, are supposed to meet the developmental challenges, bearing in mind personal resources and limitations occurring in the context of the development of an adolescent. The article presents a discussion concerning the meaning of a developing identity in using alcohol by adolescents as well as the proper understanding of teenagers' identity dilemmas when relevant psychological and pedagogical interventions are chosen.
\end{abstract}

Key words: adolescence, identity, risk behaviours, adolescents

\section{Znaczenie kształtowania się tożsamości w rozwoju młodzieży}

Fenomen tożsamości uznawany jest za niełatwy do uchwycenia na gruncie psychologii ze względu między innymi na mnogość pojęć używanych dla 
określenia zjawisk tożsamościowych (np. self, ego, jaźń), różność poglądów dotyczących wymiarów tożsamości (fenomenologiczny vs poznawczy), czy trudność w rozstrzygnięciu statusu tożsamości jako względnie stałej charakterystyki osoby lub procesu ciągłego stawania się sobą ${ }^{1}$. Generalnie uważa się, iż fenomen tożsamości odnosi się do najbardziej fundamentalnych zjawisk ludzkiej natury - pozwala na: trwałe i odrębne od innych ludzi „bycie sobą”; umiejscowienie osoby w czasie i przestrzeni; utrzymanie przeświadczenia, że Ja przetrwa mimo zmian; określenie społecznych identyfikacji poprzez konstytuowanie przeświadczenia ",bycia przynależną i tożsamą z innymi”; oraz doświadczanie siebie jako kogoś stałego i jednocześnie zmiennego².

W okresie dorastania krystalizowanie się tożsamości nabiera szczególnego znaczenia. Erik H. Erikson wprowadził pojęcie "tożsamości” jako centralnego problemu tego okresu, na który to przypada „kryzys tożsamości” ${ }^{3}$. Zdaniem Eriksona, niektórzy dorastający unikają przechodzenia przez trudny proces poszukiwań własnej tożsamości, przyjmując gotowe wzory tożsamości ukształtowane przez zbiorowość, na przykład grupę rówieśniczą. U innych w niekorzystnych warunkach wychowawczych wytwarza się opozycja względem przypisanych im ról, prowadząca do poczucia depersonalizacji i alienacji, przeżywanych jako wewnętrzna dezorganizacja i pustka (tzw. tożsamość negatywna) $)^{4}$ Sam status tożsamości negatywnej może być także traktowany jako przejaw próby wyzwolenia się spod wpływów społecznych i zaznaczenia własnej autonomii przez młodzież. Szymon Hejmanowski dostrzega możliwości rozwojowe tkwiące w przyjęciu tożsamości negatywnej przez młodego człowieka, o ile nie stanowi ona trwałego rozwiązania, a jest jedynie przejściowym etapem na drodze ku dojrzałej tożsamości psychospołecznej, na przykład przezwyciężenie rozproszenia, które pozwala odzyskać poczucie spójności i sprzyja większej aktywności w działaniu ${ }^{5}$.

${ }^{1}$ M. Jarymowicz, Psychologia tożsamości, [w:] Psychologia. Podręcznik akademicki, tom 3 - Jednostka w społeczeństwie i elementy psychologii stosowanej, red. J. Strelau, Gdańsk 2002, s. 107-125; D. Kubacka-Jasiecka, M. Kuleta, Wprowadzenie, [w:] Wkregu psychologicznej problematyki tożsamości, red. D. Kubacka-Jasiecka, M. Kuleta, Kraków 2008, s. 7-13; A. Pilarska, Ja i tożsamość a dobrostan psychiczny, Poznań 2012; A. Grzegorek, Co psycholog może mieć na myśli, kiedy mówi o tożsamości? [w:] W kręgu psychologicznej problematyki, s. 17-32; P. Oleś, Psychologia człowieka dorosłego, Warszawa 2011.

${ }^{2}$ M. Huflejt-Łukasik, Ja i procesy samoregulacji: różnice między zdrowiem a zaburzeniami psychicznymi, Warszawa 2010; D. Kubacka-Jasiecka, M. Kuleta, Wprowadzenie, s. 7-13; A. Pilarska, Ja i tożsamość; K. Sikora, Tożsamość jako przedmiot badań psychologii, [w:] W kręgu psychologicznej problematyki, s. 33-42.

${ }^{3}$ Zob. E.H. Erikson, Dzieciństwo i społeczeństwo, Poznań 1997.

${ }^{4}$ I. Obuchowska, Adolescencja, [w:] Psychologia rozwoju człowieka. Charakterystyka okresów życia człowieka, t. 2, red. B. Harwas-Napierała, J. Trempała, Poznań 2005, s. 184-185.

${ }^{5}$ Sz. Hejmanowski, Okres dorastania - zagrożenia rozwoju, Remedium, 2004, 1(131), s. 4-5. 
Wśród kontynuatorów pracy Erika H. Eriksona największą popularność zyskała opracowana przez Jamesa Marcię teoria statusów tożsamości ${ }^{6}$. Autor ten uznał eksplorację (zwaną też kryzysem) i zobowiązanie za dwa podstawowe wymiary istotne dla zdefiniowania statusu jednostki w odniesieniu do osiągnięcia tożsamości ${ }^{7}$. W procesie osiągania statusu tożsamości wyodrębniono dwa kroki: 1) eksplorację - co oznacza aktywne poszukiwanie, eksperymentowanie, próbowanie, sprawdzanie, testowanie siebie, swoich możliwości oraz relacji łączących jednostkę z innymi ludźmi, oraz 2) podjęcie zobowiązania - co oznacza przedsięwzięcie, $w$ wyniku eksploracji na etapie pierwszym, decyzji i przyjęcie na siebie odpowiedzialności za jej konsekwencje bliższe i dalsze. Kryzys jest więc momentem świadomego podejmowania decyzji (poszukiwania alternatyw), a „zobowiązanie” to osobiste zaangażowanie w jakieś zajęcie lub system przekonań (wybór ścieżki działania). Marcia uznał, że kryzys okresu adolescencji może się zakończyć przyjęciem przez młodego człowieka jednego z czterech statusów tożsamości: osiągniętej, przejętej, rozproszonej bądź moratoryjnej.

W przypadku osiągnięcia tożsamości (identity achievement) mamy do czynienia z sytuacją, kiedy obecny jest kryzys, jak również zobowiązanie. Jednostka najpierw dokonuje eksploracji siebie, rozpoznania właściwości oraz możliwości działania w otaczającym ją środowisku i eksploracji własnego umiejscowienia $\mathrm{w}$ otoczeniu, a następnie w wyniku wielokrotnych prób podejmowania różnych działań sama decyduje o dalszym postępowaniu i kierunku drogi życiowej.

Z kolei, nadanie tożsamości (foreclosed identity) to stan, w którym kryzys jest nieobecny, natomiast obecne jest zobowiązanie. Jednostka nie podejmuje eksploracji albo na skutek braku okazji, albo aktywnych działań otoczenia, hamujących jej próby samodzielnych działań. Występują też silne naciski na podjęcie zobowiązania $w$ jakiejś dziedzinie, wywierane przez otoczenie, na przykład wybór określonej szkoły. Sprzyja to kształtowaniu tożsamości lustrzanej, przybranej, nadanej, czy przyjętej od innych, ze względu na małą aktywność jednostki. Występuje silna identyfikacja z autorytetami.

Rozproszenie tożsamości (diffused identity, identity confusion) to stan obecności lub nieobecności kryzysu oraz nieobecności zobowiązania. Jednostka nie ma okazji do eksploracji, a naciski z otoczenia są na tyle silne, że musi

${ }^{6}$ J.E. Marcia, Development and Validation of Ego - Identity Status, Journal of Personality and Social Psychology, 1966, 3(5), 5, s. 551-558.

7 Zob.S. Schwartz, The Evolution of Eriksonian and Neo-Eriksonian Identity Theory and Research: a Review and Integration, Identity: An International Journal of Theory and Research, 2001, 1(1), s. 7-58; A.I. Brzezińska, K. Piotrowski, Diagnoza statusów tożsamości w okresie adolescencji, wyłaniającej się dorostości i wczesnej dorostości za pomoca Skali Wymiarów Rozwoju Tożsamości (DIDS), Studia Psychologiczne, 2009, 47(3), s. 93-109.

8 A. Brzezińska, Społeczna psychologia rozwoju, Warszawa 2000, s. 242-246. 
podjąć decyzję, zobowiązanie i odpowiedzialność za swe losy. Nie potrafi planować swojego życia, nie jest zdolna do samodzielnych wyborów i zaangażowania w wybraną działalność życiową. Kieruje się chwilową satysfakcją i własnymi korzyściami. Nie wie, kim jest i kim chce być.

Wreszcie moratorium (moratorium identity) to trwanie w kryzysie oraz obecność zobowiązania, które jest niejednoznaczne. Jednostka przez długi czas dokonuje eksploracji, ale nie czuje się gotowa do podejmowania decyzji, zaangażowania się $\mathrm{z}$ pełnym poczuciem odpowiedzialności $\mathrm{w}$ jakiś obszar aktywności. Często dlatego, że otoczenie w wystarczającym stopniu zaspokaja jej potrzeby bez jej aktywnego udziału. Jednostka dostrzega wiele alternatyw drogi życiowej, ale nie potrafi w sposób zdecydowany dokonać wyboru. Doświadcza kryzysu tożsamości, ale nie znajduje na razie odpowiedzi na pytania „kim jestem?”

Uznaje się, że określona i ukształtowana tożsamość jest podstawą funkcjonowania psychicznego człowieka i stanowi nadrzędny regulator jego psychospołecznego funkcjonowania, gdyż umożliwia określenie siebie, dokonywanie wyborów i podejmowanie zmian w życiu, wyznacza stabilność i spójność zachowań oraz zdolność do twórczej adaptacji do rzeczywistości ${ }^{10}$. Funkcja regulacyjna tożsamości, bazując na założeniu, iż jest ona przede wszystkim subiektywnym stanem osoby, związana jest z poczuciem tożsamości ${ }^{11}$. O poczuciu tożsamości stanowią składające się na nie elementy, takie jak: poczucie odrębności od otoczenia, ciągłości własnego Ja, wewnętrznej spójności, czy posiadania wewnętrznej treści ${ }^{12}$. Uformowanie zintegrowanej, odrębnej, stabilnej i niepowtarzalnej tożsamości traktowane jest jako krytyczne dla rozwoju człowieka i będące wyznacznikiem jego psychospołecznej dojrzałości ${ }^{13}$. Z perspektywy rozwojowej i klinicznej istotne jest, iż oparcie tożsamości na stabilnych fundamentach zapewnia człowiekowi poczucie bezpieczeństwa ${ }^{14}$. Trudności w zakresie ukształtowania dojrzałej i stabilnej tożsamości, naruszenie poczucia tożsamości, niejasność w ważnych dla jednostki dziedzinach życia mogą generować lęk, niepokój i agresję, i prowadzić do różnorodnych form patologii indywidualnej i społecznej, a także negatywnie wpływać na

9 Tamże.

10 E.H. Erikson, Dzieciństwo i społeczeństwo; M. Huflejt-Łukasik, Ja i procesy samoregulacji; M. Sokolik, Psychoanaliza i Ja: kliniczna problematyka poczucia tożsamości, Warszawa 2000.

11 M. Jarymowicz, Psychologia tożsamości, s. 107-125; M. Huflejt-Łukasik, Ja i procesy samoregulacji; M. Sokolik, Psychoanaliza i Ja.

${ }^{12} \mathrm{~J}$. Mandrosz-Wróblewska, Strategie redukowania problemów tożsamościowych: różnicowanie "Ja - My" i "My - Oni", [w:] Studia nad spostrzeganiem relacji Ja - Inni: tożsamość, indywiduacja przynależność, red. M. Jarymowicz, Wrocław 1988, s. 125-161; K. Sikora, Tożsamość jako przedmiot badań, s. 33-42; M. Sokolik, Psychoanaliza i Ja.

13 E.H. Erikson, Dzieciństwo i społeczeństwo; A. Pilarska, Ja i tożsamość.

14 E.H. Erikson, Dzieciństwo i społeczeństwo; M. Sokolik, Psychoanaliza i Ja. 
emocjonalny dobrostan jednostki ${ }^{15}$. Zaburzenia tożsamości mogą przejawiać się również w takich zjawiskach, jak: poczucie utraty granic między Ja a światem zewnętrznym, brak wewnętrznej treści, poczucie pustki, brak wiedzy kim się jest, brak poczucia ciągłości ze sobą z przeszłości, poczucie rozbicia Ja na części, brak wewnętrznej spójności, utrata poczucia istnienia, czy poczucie nierzeczywistości własnego istnienia ${ }^{16}$.

\section{Zachowania ryzykowne młodzieży a rozwój tożsamości w okresie adolescencji}

Zachowania ryzykowne adolescentów i adolescentek, w tym używanie alkoholu, mogą być rozumiane jako zachowania, które młodzież podczas rozwoju podejmuje jako środek do osiągnięcia ważnych dla tego rozwoju celów, między innymi konstruowania tożsamości. Zachowania ryzykowne można zdefiniować jako

zachowania podejmowane w okresie adolescencji, które mają na celu sprostanie wyzwaniom rozwojowym, a ich wybór zależy od tego, jakimi zasobami dysponuje młodzież, jakich doświadcza czynników ryzyka, oraz w jaki sposób młodzi ludzie poradzili sobie z wyzwaniami wcześniejszych etapów życia - są formą adaptacji, ale także mają na celu określenie siebie, swojego miejsca w świecie, wśród rówieśników i dorosłych - mogą więc być formą (auto)kreacji ${ }^{17}$.

Zdaniem Heleny Sęk i Łukasza D. Kaczmarka, same procesy rozwojowe mogą świadczyć o ryzyku:

Kryzysy rozwojowe stanowią typowy układ, który można nazwać układem ryzykownych szans. Nasilenie konfliktu i sprzeczności zwiększa prawdopodobieństwo nierozwiązania kryzysu lub stosowania patologicznych strategii przezwyciężania go. Aby móc rozwiązać kryzys, potrzebne jest podejmowanie ryzykownych, nowych zadań - dlatego mówi się o ryzyku rozwojowym ${ }^{18}$.

Silvia Bonino, Elena Cattelino i Silvia Ciairano podkreślają, że młodzież nie działa w przypadkowy sposób, ale taki, aby osiągnąć osobiste istotne

${ }^{15}$ E.H. Erikson, Dzieciństwo $i$ społeczeństwo; D. Kubacka-Jasiecka, Autodestruktywna tożsamość a kryzys emocjonalny, [w:] W kręgu psychologicznej problematyki, s. 253-275; A. Pilarska, Ja i tożsamość.

${ }^{16}$ E.H. Erikson, Dzieciństwo i społeczeństwo; R.D. Laing, Podzielone "ja". Egzystencjalistyczne studium zdrowia i choroby psychicznej, Poznań 1999; M. Sokolik, Psychoanaliza i Ja.

${ }_{17}$ B. Jankowiak, Zachowania ryzykowne młodzieży. Studium teoretyczno-empiryczne, Poznań 2017, s. 447.

${ }^{18}$ H. Sęk, Ł.D. Kaczmarek, Promocja zdrowia i prewencja zaburzeń, [w:] Psychologia kliniczna, red. L. Cierpiałkowska, H. Sęk, Warszawa 2016, s. 666. 
cele, związane z zadaniami rozwojowymi w określonym kontekście (action in context). Tak więc działania młodzieży, niezależnie czy niebezpieczne i antyzdrowotne, czy bezpieczne i zdrowe, mają ściśle określoną funkcję, ponieważ mogą służyć osiągnięciu osobistych i społecznych znaczących celów wzrostu podczas okresu adolescencji ${ }^{19}$. Autorki te podzieliły funkcje zachowań ryzykownych na dwa główne, ściśle powiązane, obszary odnoszące się do: 1) rozwoju tożsamości (takie jak: manifestowanie zachowań oznaczających dorosłość, nabycie i afirmacja niezależności, identyfikacja i różnicowanie, autoafirmacja i eksperymenty, transgresja i przekraczanie granic, eksploracja doznań, kształtowanie poczucia kontroli w sytuacjach niebezpiecznych, radzenie sobie z problemami i ucieczka od rzeczywistości) oraz 2) udziału w społeczeństwie (takie jak: komunikacja międzyrówieśnicza, współdzielenie działań i emocji, rytuały tworzenia więzi i obrzędy przejścia, naśladowanie i rywalizowanie, badanie reakcji i ograniczeń, różnicowanie od rodziców i sprzeciw wobec nich). Podstawowym zadaniem rozwojowym w okresie dojrzewania, które można osiągnąć poprzez specyficzne i zróżnicowane zadania dzięki kulturze, jest konstruowanie własnej tożsamości. Funkcje różnych typów zachowań ryzykownych w okresie dojrzewania są ściśle związane właśnie dlatego, że odnoszą się do budowania autonomicznej tożsamości osoby dorosłej.

Barbara Jankowiak podzieliła funkcje zachowań ryzykownych młodzieży na progresywne i regresywne. Zachowania ryzykowne spełniające funkcje progresywne mają na celu radzenie sobie z zadaniami rozwojowymi okresu dojrzewania (np. separacja od rodziców, budowanie nowych form relacji, poznanie siebie, poszukiwanie własnego miejsca $w$ grupie, ustalenie na nowo własnych relacji z dorosłymi) oraz dostarczenie odpowiedzi na podstawowy dylemat dotyczący tożsamości. Pomimo ryzyka, jakie niosą, wyrażają tendencje rozwojowe nastolatków. Zachowania ryzykowne spełniające funkcje regresywne motywowane są problemami, traumami i deficytami rozwojowymi, z którymi młody człowiek wkracza w nowy etap życia, w którym czekają na niego nowe wyzwania. Młodzi ludzie próbują poradzić sobie z przeszłością w obliczu aktualnych zmian rozwojowych, podejmując zachowania ryzykowne w teraźniejszości. Tak motywowane zachowania ryzykowne lokują młodych ludzi coraz bliżej obszaru psychopatologii ${ }^{21}$.

Możliwe jest dokonanie klasyfikacji zachowań ryzykownych uwzględniając ich funkcje (progresywne vs regresywne) oraz nasilenie. Zarówno zachowań spełniających funkcję progresywną, jak i regresywną może być mało lub

${ }^{19}$ S. Bonino, E. Cattelino, S. Ciairano, Adolescents and Risk. Behavior, Functions, and Protective Factors, Italia 2005, s. 6-13.

${ }^{20}$ Tamże.

${ }^{21}$ B. Jankowiak, Zachowania ryzykowne młodzieży, s. 445. 
dużo, co stanowi dodatkową informację o sposobie adaptacji młodego człowieka. Uwzględniając te kryteria, można wyróżnić cztery kategorie zachowań ryzykownych: eksploracyjne, kryzysowe, unikające i deficytowe (patrz ryc. 1).

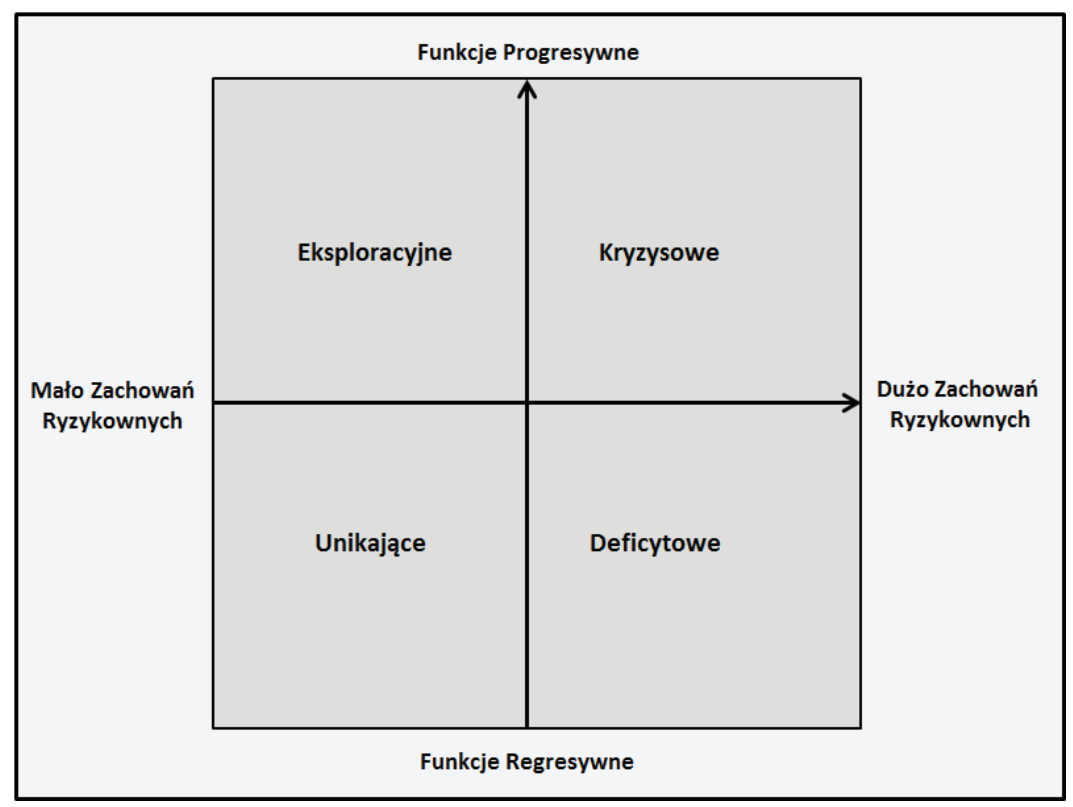

Ryc. 1. Eksploracyjne, kryzysowe, unikające i deficytowe zachowania młodzieży

Źródło: B. Jankowiak, Zachowania ryzykowne młodzieży. Studium teoretyczno-empiryczne, Poznań 2017, s. 389.

Zachowania ryzykowne eksploracyjne są niezbyt nasilone i motywowane naturalną rozwojową eksploracją, poszukiwaniem siebie, swojego miejsca w grupie, ustalaniem swojego nowego statusu społecznego. Młodzież może na przykład próbować alkoholu, który jest przeznaczony dla osób dorosłych, gdyż zaczyna czuć się dorosła. Zachowania te niosą ze sobą pewne ryzyko, ale jednocześnie świadczą o tendencjach rozwojowych młodzieży ${ }^{22}$.

Zachowania ryzykowne kryzysowe są dużo bardziej nasilone, niż zachowania z grupy poprzedniej, choć także motywowane tendencjami rozwojowymi. Świadczą o silnym kryzysie rozwojowym i stanowią większe zagrożenie. Młodzi ludzie podejmując takie zachowania wprowadzają do swojej aktywności więcej destrukcji, na przykład korzystając ze środków psychoaktywnych czy intensywnie i regularnie imprezując. Młodzi ludzie próbują rozwiązać kryzys adolescencyjny przy braku wystarczających zasobów. Za-

${ }^{22}$ B. Jankowiak, Zachowania ryzykowne młodzieży, s. 389-390. 
chowania te niosą ze sobą większe zagrożenie zarówno dla bezpieczeństwa młodych ludzi, jak też ich zdrowia i dalszych sukcesów życiowych ${ }^{23}$.

Zachowania ryzykowne unikające są niezbyt nasilone i motywowane głównie trudnościami z poprzednich etapów życia. Mają na celu odciąć od problemów i emocji (np. poprzez picie alkoholu), by nie podejmować wyzwań rozwojowych. Funkcjonowanie młodzieży w tym obszarze świadczy o występowaniu wielu czynników ryzyka (przy ubogich czynnikach chroniących) w ich rozwoju, może więc wskazywać na zwiększone ryzyko rozwoju psychopatologii (w tym przypadku najprawdopodobniej zaburzeń internalizacyjnych). Zagrożenie nie wynika tutaj zazwyczaj z samych ryzykownych zachowań, co raczej z braku zasobów do radzenia sobie z wyzwaniami rozwojowymi, które spowodowały zahamowanie rozwoju i taki sposób adaptacji ${ }^{24}$.

Zachowania ryzykowne deficytowe są nasilone i mocno zagrażające rozwojowi, a motywowane występowaniem doświadczeń stresujących (np. niezaspokojenie potrzeb, konflikty w rodzinie), jak i traumatycznych w biografii młodzieży. Mogą polegać na przykład na intensywnym korzystaniu ze środków psychoaktywnych, aby poradzić sobie z bolesnymi wspomnieniami. W rozwoju nastolatków funkcjonujących $w$ taki sposób występowało niewiele czynników chroniących rozwój, a wiele czynników ryzyka powstania psychopatologii, co może dać negatywny efekt w postaci zaburzeń eksternalizacyjnych, ale także internalizacyjnych ${ }^{25}$.

Zachowania ryzykowne młodzieży należy więc rozumieć jako zachowania podejmowane $\mathrm{w}$ okresie dojrzewania, które mają na celu realizację wyzwań tego okresu z uwzględnieniem czynników ryzyka i czynników chroniących zarówno w jednostce, jak i kontekście jej rozwoju. Dlatego, do wyboru właściwych interwencji psychologiczno-pedagogicznych nie wystarczy samo stwierdzenie faktu, że młodzi ludzie piją alkohol, należy także określić, z jakiego powodu to robią - a kwestie dotyczące tożsamości mogą być w rozstrzygnięciach diagnostycznych szczególnie istotne.

\section{Używanie alkoholu przez młodzież a rozwój tożsamości w okresie adolescencji}

Alkohol stanowi najczęściej używaną przez młodzież w Polsce substancję psychoaktywną ${ }^{26}$. Dane dotyczące występowania problemu używania

${ }^{23}$ Tamże, s. 390-392.

${ }^{24}$ Tamże, s. 392-394.

${ }^{25}$ Tamże, s. 394-396.

${ }^{26}$ Za: K. Ostaszewski, Zapobieganie używaniu substancji psychoaktywnych, [w:] Edukacja zdrowotna, red. B. Woynarowska, Warszawa 2013, s. 487. 
alkoholu przytoczono na podstawie badań empirycznych, opierając się na informacjach z projektu ESPAD ${ }^{27}$ oraz $\mathrm{HBSC}^{28}$. Analiza międzynarodowych wyników badań ESPAD wykazała, że we wszystkich krajach uczestniczących w projekcie, poza Islandią, co najmniej 70\% uczniów piło alkohol przynajmniej raz w życiu, przy czym w badaniach ankietowych z 2011 roku średnia wyniosła 87\%. Jeżeli chodzi o spożywanie alkoholu w ciągu ostatnich 12 miesięcy i ostatnich 30 dni, to średnie odsetki wynoszą odpowiednio 79\% i 57\%. W odniesieniu do wszystkich trzech przedziałów czasowych wystąpiły małe spadki od 2003 roku w stosunku do lat 2007 i 2011. Pytano także uczniów, jak często w ciągu ostatnich 30 dni spożywali co najmniej pięć standardowych porcji alkoholu przy jednej okazji. Ten wskaźnik „okazjonalnego spożywania dużej ilości alkoholu” uległ jednej z najgwałtowniejszych zmian wśród dziewcząt na przestrzeni wszystkich lat realizacji projektu ESPAD - średnia zagregowana wzrosła z 29\% w 1995 roku do 41\% w 2007 roku. W badaniu ankietowym z 2011 roku wartość ta spadła jednak do 38\%. Wśród chłopców dane te również były w 2011 roku nieco niższe (43\%) niż w 2007 (45\%) i tym samym również stosunkowo zbliżone do wartości z 1995 roku (41\%). Średnia różnica między chłopcami i dziewczętami zmniejszyła się z 12 punktów procentowych w 1995 roku do 5 punktów procentowych w 2011 roku, ale w 22 krajach uczestniczących w projekcie ESPAD nawet w najnowszym badaniu ankietowym znacznie więcej chłopców niż dziewcząt zgłosiło okazjonalne spożywanie dużej ilości alkoholu ${ }^{29}$.

Anna Dzielska poddała analizie wyniki badań HBSC odnośnie picia alkoholu polskich nastolatków. Wyniki badań wskazują, że obecnie jakikolwiek napój alkoholowy spożywa 42,6\% nastolatków w wieku 11-15 lat, w tym 6,4\% co najmniej raz w tygodniu. Stwierdzono również, że co piąty nastolatek upił się co najmniej raz w życiu (21,1\%), a 3,2\% zrobiło to więcej niż 10 razy. W stosunku do wyników poprzednich badań HBSC, obserwuje się zarówno istotny spadek ogólnej częstości picia, jak i upijania się przez młodzież w tej grupie wieku. Częstość ogólnego picia zmniejszyła się u obu płci. Częstość upijania się zmniejszyła się istotnie u chłopców, zwiększając się jednak u dziewcząt. Coraz częściej upijają się dzieci w wieku 11 lat oraz coraz większy odsetek ankietowanych deklaruje codzienne picie alkoholu (2,5\% vs 3,1\%). Uzyskane wyniki pokazują, że częstość picia i upijania się są zbliżone u obu płci i na-

${ }^{27}$ European School Survey Project on Alcohol and Other Drugs (ESPAD), zob: B. Hibell $\mathrm{i}$ in., The 2011 ESPAD report. Substance use among students in 36 European countries, Szwedzka Rada ds. Informacji o Alkoholu i Innych Używkach, Sztokholm 2012.

${ }^{28}$ Health Behaviour in School-aged Children (HBSC), zob: J. Mazur, (red.), Zdrowie i zachowania zdrowotne młodzieży szkolnej w Polsce na tle wybranych uwarunkowań socjodemograficznych. Wyniki Badań HBSC 2014, Instytut Matki i Dziecka, Warszawa 2015.

${ }^{29}$ Zob. B. Hibell i in., The 2011 ESPAD report, s. 5-8. 
silają się wraz z wiekiem, szczególnie między 13 a 15 rokiem życia. Według aktualnych wyników badań HBSC, 34,9\% nastolatków po raz pierwszy piło alkohol w wieku 13 lat lub mniej, a 9,2\% upiło się po raz pierwszy w tak wczesnym wieku. W porównaniu z wynikami badań HBSC z roku 2010 obserwuje się istotne zmiany głównie $\mathrm{w}$ zakresie wczesnej inicjacji picia; odpowiedni odsetek zmniejszył się z 47,8\%. Korzystne zmiany dotyczą tu obu płci. W badanym okresie na bardzo zbliżonym poziomie utrzymała się wczesna inicjacja upijania się, co jest konsekwencją przeciwstawnych tendencji u obu płci. Odsetek chłopców, którzy po raz pierwszy upili się przed 14 rokiem życia, zmniejszył się z 13,4\% do 9,7\%, podczas gdy odpowiedni odsetek dziewcząt zwiększył się z 5\% do 8,7\%. Oznacza to zniwelowanie różnic związanych z płcią o 7,4 punktu procentowego. Można stwierdzić, że średnio mija niecały rok między pierwszym epizodem wypicia alkoholu i upicia się. Różnice związane z płcią są niewielkie - chłopcy istotnie wcześniej sięgają po raz pierwszy po alkohol, podczas gdy różnice w średnim wieku upicia się po raz pierwszy są nieistotne ${ }^{30}$.

W literaturze z obszaru uzależnień, osoby nadużywające alkoholu i uzależnione widziane są jako cierpiące $\mathrm{z}$ powodu patologii $\mathrm{w}$ zakresie relacji przywiązaniowych ${ }^{31}$, co skutkuje deficytami tożsamości: niezdolnością do utrzymania spójnego i zadowalającego konceptu siebie ${ }^{32}$, kruchością i zagrożeniem poczucia bycia oraz reprezentacji $\operatorname{siebie}^{33}$, zranieniem i uszkodzeniem self ${ }^{34}$, przeżywaniem nieświadomej, głębokiej niepewności dotyczącej prawa do istnienia, posiadania odrębnej tożsamości i utraty poczucia tożsamości ${ }^{35}$. Teoretycy i badacze charakteryzują tożsamość osób uzależnionych jako pewien rodzaj głębokiej struktury psychicznej, pierwotnie w stosunku do uzależnienia kruchej i uszkodzonej. Przy takim założeniu, uzależnienie od alkoholu staje się sposobem zyskiwania nowej tożsamości - jako uzależnionego - i ta tożsamość ma chronić zarówno przed przeszłością, jak i przyszłością

${ }^{30}$ A. Dzielska, Picie alkoholu, [w:] Zdrowie i zachowania zdrowotne młodzieży szkolnej.

${ }^{31}$ P.J. Flores, Addiction as an attachment disorder, Lanham 2004; J.D. Levin, Treatment of alcoholism and other addictions. A self-psychology approach, New Jersey - London 1991.

32 E.J. Khantzian, Treating addiction as a human process, Lanham 2007.

${ }^{33}$ D.Z. Höfler, M. Kooyman, Attachment transition, addiction and therapeutic bonding - an integrative approach, Journal of Substance Abuse Treatment, 1996, 13(6), s. 511-519; J.D. Levin, Treatment of alcoholism and other addictions; F.A. Thorberg, M. Lyvers, Attachment, fear of intimacy and differentiation of self among clients in substance disorder treatment facilities, Addictive Behaviors, 2006, 31(4), s. 732-737.

${ }^{34}$ P.J. Flores, Addiction as an attachment disorder; H. Kohut, Preface, [w:] Psychodynamics of drug dependence. NIDA Research Monograph 12, red. J.D. Blaine, D.A. Julius, Washington 1977, s. vii-ix; K.S. Sachs, Treating alcoholism as a disorder of the self: insights from alcoholics anonymous, Alcoholism Treatment Quarterly, 2003, 21(2), s. 75-85.

${ }^{35}$ H. Kohut, Preface, s. vii-ix; J. Morgenstern, J. Leeds, Contemporary psychoanalytic theories of substance abuse: a disorder in search of a paradigm, Psychotherapy, 1993, 30(2), s. 194-206. 
oraz określić - dotychczas nieokreślone z powodu braku bezpiecznego poczucia tożsamości - miejsce w świecie ${ }^{36}$. Nadużywanie alkoholu, a w dalszej perspektywie uzależnienie od niego, staje się próbą naprawy stanu przytłaczającej beznadziejności powodowanej zniszczoną tożsamością ${ }^{37}$, złamanym poczuciem self ${ }^{38}$, oraz stanowi formę obrony przed dalszą fragmentacją self ${ }^{39}$. Spostrzegane jest jako walka na śmierć i życie o utrzymanie żywego poczucia siebie, wciąż zagrożonego masywnymi wątpliwościami dotyczącymi własnej osoby $^{40}$. Z drugiej zaś strony, uzależnienie od alkoholu wtórnie traumatyzuje osobę, opróżniając ją z żywotności, tożsamości i wewnętrznego bogactwa ${ }^{41}$ oraz dokonując erozji poczucia siebie ${ }^{42}$.

Doniesienia z badań prowadzonych wśród młodzieży wskazują, iż rozwój tożsamości znacząco wpływa na regulowanie ilości spożywanego alkoholu. Dowiedziono odwrotną korelację między statusem tożsamości, jej dojrzałości a ilością i częstotliwością spożywania alkoholu. Młodzież z tożsamością rozproszoną i nadaną spożywała znacząco większe ilości alkoholu niż młodzież z tożsamością osiągniętą, czy znajdująca się w stanie moratorium. Dodatkowo, opierając się na wynikach badań podłużnych, okazuje się, że osoby z rozproszoną tożsamością oraz tożsamością słabiej zmieniającą się w czasie dojrzewania spożywają znacznie więcej alkoholu niż osoby ze statusem tożsamości skonsolidowanej, osiągniętej oraz których tożsamość bardziej ewoluowała w trakcie dojrzewania. Ponadto, badacze porównując profil tożsamości grupy adolescentów nadużywających alkoholu i uczestniczących w programie leczenia uzależnień w warunkach stacjonarnych z niekliniczną grupą adolescentów, dowiedli, iż grupa kliniczna prezentuje wyższy poziom nadania tożsamości, a niższy poziom moratorium i osiągnięcia tożsamości ${ }^{43}$.

${ }^{36}$ A. Read, Psychotherapy with addicted people, [w:] The psychodynamics of addiction, red. M. Weegmann, R. Cohen, London - Philadelphia 2006, s. 85-98; J. Holmes, Attachment theory and psychoanalysis: a rapprochement, British Journal of Psychotherapy, 2000, 17(2), s. 157-172.

37 L.M. Dodes, The heart of addiction. A new approach to understanding and managing alcoholism and other addictive behaviors, New York 2003.

${ }^{38}$ K. Kueppenbender i in., "Narcotics helped, I thought." Recurrent traumatization and recovery from drug dependence, Harvard Review of Psychiatry, 2008, 16, s. 308-317; E.J. Khantzian, M. Albanese, Understanding addiction as self-medication. Finding hope behind the pain, Lanham 2008.

${ }^{39}$ J.D. Levin, Treatment of alcoholism and other addictions.

40 D.B. Jones, Addiction and pathological accommodation: an intersubjective look an impediments to the utilization of Alcoholics Anonymous, The International Journal of Psychoanalytic Self Psychology, 2009, 4, s. 212-234.

${ }^{41}$ M. Weegmann, E.J. Khantzian, Envelopments: immersion in and emergence from drug misuse, American Journal of Psychotherapy, 2011, 65(2), s. 163-177.

${ }^{42}$ N.L. Padykula, P. Conklin, The self regulation model of attachment trauma and addiction, Clinical Social Work Journal, 2010, 38(4), s. 351-360.

${ }^{43}$ D.I. Bishop i in., Identity development and alcohol consumption: current and retrospective self-reports by college students, Journal of Adolescence, 2005, 28, s. 523-533; D.I. Bishop i in., Ego identity status and reported alcohol consumption: a study of first-year college students, Journal of Ado- 
Z szeroko zakrojonych badań Hardy'ego i współpracowników ${ }^{44}$ wynika z kolei, iż dojrzała tożsamość jest kluczem zdrowego psychospołecznego funkcjonowania i może być czynnikiem ochronnym; jednostki charakteryzujące się syntezą tożsamości spożywają znacząco mniej alkoholu, a ponadto przejawiają mniejsze nasilenie lęku i depresji, wyższe poczucie własnej wartości i psychologicznego dobrobytu. Analogicznie, brak klarownego i stabilnego poczucia siebie oraz poczucie niepewności „kim jestem” mogą motywować nieadaptacyjne zachowania jako sposoby utrzymania tożsamości i ucieczki od dyskomfortu związanego z negatywną emocjonalnością. Udowodniono bowiem, iż negatywne schematy dotyczące własnej osoby we wczesnej adolescencji bezpośrednio wyjaśniają wczesny początek inicjacji alkoholowej, niezależnie od występowania alkoholizmu w rodzinie i poziomu antyspołeczności ${ }^{45}$. Co dodatkowo ważne, uznaje się, że przeszło $80 \%$ adolescentów uzależnionych od alkoholu spełnia kryteria innych zaburzeń psychiatrycznych, w tym około $20 \%$ - zaburzeń internalizacyjnych, około $35 \%$ - zaburzeń eksternalizacyjnych, a pozostałe $45 \%$ - zarówno internalizacyjnych, jak i eksternalizacyjnych. Jednocześnie podkreśla się, że wystąpienie uzależnienia od alkoholu u młodzieży częściej będzie problemem wtórnym wobec pierwotnie występujących innych zaburzeń ${ }^{46}$.

\section{Pomoc psychologiczno-pedagogiczna ukierunkowana na wsparcie rozwoju tożsamości w okresie adolescencji oraz przeciwdziałanie zachowaniom ryzykownym}

Jak wykazano wcześniej, podejmowanie różnych zachowań ryzykownych, w tym używanie alkoholu przez młodzież, może być wynikiem radzenia sobie z kryzysem tożsamościowym okresu dojrzewania. Pomoc psychologiczno-pedagogiczna skierowana na przeciwdziałanie lub terapię młodzieży

lescence, 1997, 20(2), s. 209-18; S.J. Schwartz i in., Identity consolidation and health risk behaviors in college students, American Journal of Health Behavior, 2010, 34(2), s. 214-224; E.M. Bentrim-Tapio, Alcohol consumption in undergraduate students: the role of ego-identity status, alcohol expectancies, and drinking refusal self-efficacy, NASPA Journal, 2004, 41(4), s. 728-741.

${ }^{44}$ S.A. Hardy i in., The roles of identity formation and moral identity in college student mental health, health-risk behaviors, and psychological well-being, Journal of Clinical Psychology, 2013, 69(4), s. 364-382.

${ }^{45}$ C. Corte, R.A. Zucker, Self-concept disturbances: Cognitive vulnerability for early drinking and early drunkenness in adolescents at high risk for alcohol problems, Addictive Behaviors, 2008, 33, s. 1282-1290.

${ }^{46}$ C.A. Essau, D. Hutchinson, Alcohol use, abuse and dependence, [w:] Adolescent addiction: epidemiology, assessment and treatment, red. C.A. Essau, London 2008, s. 61-115. 
podejmującej zachowania ryzykowne powinna więc uwzględniać problematykę rozwoju tożsamości i wspierać młodych ludzi w jej konstruowaniu. Współcześnie w działaniach profilaktycznych w odniesieniu do młodzieży podąża się w kierunku zintegrowanego podejścia do zapobiegania używaniu substancji psychoaktywnych: alkoholu, tytoniu, narkotyków, leków psychoaktywnych, ze względu na wiele cech wspólnych ${ }^{47}$, na przykład wspólne czynniki ryzyka czy współwystępowanie oraz na wspólne funkcje, które spełniają różne zachowania ryzykowne ${ }^{48}$. Naukowcy zajmujący się profilaktyką zwracają uwagę na znaczenie interwencji profilaktycznych w czasie ważnych zmian życiowych - zarówno biologicznych, takich jak dojrzewanie płciowe, jak i normatywnych zmian w funkcjonowaniu społecznym, takich jak przejście ze szkoły podstawowej do szkoły średniej, czy też urazów, takich jak śmierć lub utrata rodzica ${ }^{49}$. Ponadto, zdaniem Krzysztofa Ostaszewskiego, $\mathrm{w}$ ostatnich latach nastąpiła zmiana w podejściu do profilaktyki używania substancji psychoaktywnych polegająca na rozumieniu uzależnienia (alkoholizmu, narkomanii, lekomanii, nikotynizmu) jako jednego z wielu zagrożeń wynikających z używania substancji - ale nie głównego i jedynego - jak to było wcześniej ${ }^{50}$. Obecnie podkreśla się znaczenie innych problemów poza uzależnieniem, do których zalicza się inne szkody zdrowotne (np. zatrucia, infekcje, zaburzenia psychiczne) oraz wypadki, samobójstwa, przestępstwa, konflikty, zaniedbywanie dzieci, przemoc domową, akty agresji i inne czyny popełniane pod wpływem alkoholu, narkotyków i innych substancji psychoaktywnych. Można więc mówić o zróżnicowanych szkodach zdrowotnych i społecznych, będących konsekwencjami używania substancji ${ }^{51}$. Interwencje profilaktyczne mają na celu zapobieganie inicjacji używania substancji psychoaktywnych i jego progresji do uzależnienia, a interwencje terapeutyczne przeznaczone są dla osób uzależnionych ${ }^{52}$.

Aby wspierać młodzież w kształtowaniu tożsamości, należy ją zachęcać do próbowania swoich sił w różnych dziedzinach i aktywnościach ${ }^{53}$. Jednak „młody człowiek potrzebuje od dorosłego adekwatnego i dojrzałego wspar-

${ }^{47}$ K. Ostaszewski, Zapobieganie, s. 491; T.P. Gullotta, A Selected Social History of the Stepping-Stone Drugs, [w:] Adolescent Substance Abuse Evidence-Based Approaches to Prevention and Treatment, red. C.G. Leukefeld, T.P. Gullotta, M. Staton-Tindall, New York 2009, s. 1-15.

${ }^{48}$ R. Jessor, Risk Behavior in Adolescence: A Psychosocial Framework for Understanding and Action, Journal of Adolescent Health, 199112.

${ }^{49}$ E.B. Robertson i in., Drug use prevention: definitions and terminology, [w:] Handbook of Adolescent Drug Use Prevention: Research, Intervention Strategies, and Practice, red. L.M. Scheier, American Psychological Association 2015, s. 15.

${ }^{50}$ K. Ostaszewski, Zapobieganie, s. 488.

51 Tamże, s. 488-489.

${ }^{52}$ E.B. Robertson i in., Drug use prevention, s. 12.

${ }^{53}$ W. Pawliczuk, Poradnictwo psychologiczne w okresie adolescencji, [w] Poradnictwo psychologiczne, red. Cz. Czabała, S. Kluczyńska, Warszawa 2015, s. 117. 
cia, różnego w zależności od etapu, na którym się znajduje" ${ }^{54}$. Zdaniem Bardziejewskiej, na etapie tożsamości rozproszonej są to silne i stabilne wzorce zewnętrzne, reguły oraz wsparcie autorytetów oraz jasnych zasad, co może skutkować chwilowym przejściem do etapu tożsamości lustrzanej poprzez przyjęcie systemu wartości dorosłego przewodnika. Aby przejść na etap tożsamości moratoryjnej, dorastający potrzebuje dorosłego - doradcy, który pozwoli na samodzielne poszukiwania i odkrywanie własnych zainteresowań. Przechodząc na etap tożsamości dojrzałej, młody człowiek potrzebuje konsultanta, który pozwoli na samodzielne analizowanie korzyści i zagrożeń wynikających z samodzielnie podejmowanych decyzji55.

Warto również podkreślić, że w zależności od nasilenia zachowań ryzykownych i skali zagrożenia, jakie się z nimi wiążą dla rozwoju i zdrowia nastolatka, podejmowane będą inne interwencje psychologiczno-pedagogiczne. $\mathrm{Na}$ przykład, młodzi ludzie podejmujący zachowania ryzykowne eksploracyjne mogą potrzebować oddziaływań potęgujących zasoby, na przykład promujących zdrowy styl życia, profilaktycznych lub edukacyjnych ${ }^{56}$. Młodzież, która podejmuje zachowania ryzykowne kryzysowe może potrzebować przede wszystkim interwencji pomocowych ukierunkowanych na rozwiązywanie kryzysu rozwojowego ${ }^{57}$. Adolescenci i adolescentki podejmujący zachowania ryzykowne unikające w zależności od postawionej diagnozy mogą potrzebować wsparcia w rozwoju, socjoterapii, psychoterapii, terapii uzależnień lub nawet leczenia psychiatrycznego. Interwencje mogą - co szczególnie istotne w podejmowaniu działań pomocowych dla dzieci i młodzieży ${ }^{58}$ - obejmować edukację i trening umiejętności dla rodziców, a także oddziaływać na kontekst rozwoju nastolatka, na przykład na rodzinę i szkołę ${ }^{59}$. Natomiast, dla nastolatków podejmujących zachowania ryzykowne deficytowe działania z obszaru profilaktyki mogą być niewystarczające, a w zależności od postawionej diagnozy, młodzi mogą być kierowani na socjoterapię, psychoterapię, terapię uzależnień lub nawet leczenie psychiatryczne, a interwencje - tak jak w poprzedniej grupie zachowań - powinny obejmować rodziców, a także inne (poza rodziną) konteksty rozwoju młodego człowieka, na przykład szkołę ${ }^{60}$.

${ }^{54}$ M. Bardziejewska, Okres dorastania. Jak rozpoznać potencjał nastolatków? [w:] Psychologiczne portrety człowieka. Praktyczna psychologia rozwojowa, red. A.I. Brzezińska, Gdańsk 2015, s. 370.

${ }_{55}$ Tamże, s. 373-374.

${ }^{56}$ B. Jankowiak, Zachowania ryzykowne młodzieży, s. 392.

${ }_{57}$ Zob. A.I. Brzezińska, K. Appelt, A. Ziółkowska Psychologia rozwoju człowieka, [w:] Psychologia akademicka, t. 2, red. J. Strelau, D. Doliński, Gdańsk 2011, s. 248.

${ }_{58}$ Zob. I. Grzegorzewska, E. Pisula, A.R. Borkowska, Psychologia kliniczna dzieci i młodzieży, [w:] Psychologia kliniczna, s. 460.

59 B. Jankowiak, Zachowania ryzykowne młodzieży, s. 394.

${ }^{60}$ Tamże, s. 396. 
Picie alkoholu przez młodzież w okresie adolescencji może spełniać różne funkcje, także związane z kształtowaniem się tożsamości. Jednocześnie stwarza ono ryzyko dla zdrowia i dalszego życia nastolatków. Działania profilaktyczne w tym obszarze powinny uwzględniać potrzeby młodych ludzi związane z określaniem siebie i umożliwić im osiągnięcie celów rozwojowych w zdrowy i bezpieczny sposób. Z drugiej strony, kiedy profilaktyka i edukacja są niewystarczające, konieczna jest indywidualna diagnoza i skierowanie młodego człowieka do bardziej specjalistycznych form pomocy - na przykład terapii uzależnień.

\section{BIBLIOGRAFIA}

Bardziejewska M., Okres dorastania. Jak rozpoznać potencjał nastolatków? [w:] Psychologiczne portrety człowieka. Praktyczna psychologia rozwojowa, red. A.I. Brzezińska, Gdańskie Wydawnictwo Psychologiczne, Gdańsk 2015.

Bentrim-Tapio E.M., Alcohol consumption in undergraduate students: the role of ego-identity status, alcohol expectancies, and drinking refusal self-efficacy, NASPA Journal, 2004, 41(4).

Bishop D.I., Macy-Lewis J.A., Schnekloth C.A., Puswella S., Struessel G.L., Ego identity status and reported alcohol consumption: a study of first-year college students, Journal of Adolescence, 1997, 20(2).

Bishop D.I., Weisgram E.S., Holleque K.M., Lund K.E., Wheeler-Anderson J.R., Identity development and alcohol consumption: current and retrospective self-reports by college students, Journal of Adolescence, 2005, 28.

Bonino S., Cattelino E., Ciairano S., Adolescents and Risk. Behavior, Functions, and Protective Factors, Springer-Verlag, Italia 2005.

Brzezińska A., Społeczna psychologia rozwoju, Wydawnictwo Naukowe Scholar, Warszawa 2000.

Brzezińska A.I., Appelt K., Ziółkowska A., Psychologia rozwoju człowieka, [w:] Psychologia akademicka, t. 2, red. J. Strelau, D. Doliński, Gdańskie Wydawnictwo Psychologiczne, Gdańsk 2011.

Brzezińska A.I., Piotrowski K., Diagnoza statusów tożsamości w okresie adolescencji, wyłaniającej się dorostości $i$ wczesnej dorostości za pomoca Skali Wymiarów Rozwoju Tożsamości (DIDS), Studia Psychologiczne, 2009, 47(3).

Corte C., Zucker R.A., Self-concept disturbances: Cognitive vulnerability for early drinking and early drunkenness in adolescents at high risk for alcohol problems, Addictive Behaviors, $2008,33$.

Dodes L.M., The heart of addiction. A new approach to understanding and managing alcoholism and other addictive behaviors, Harper, New York 2003.

Dzielska A., Picie alkoholu, [w:] Zdrowie i zachowania zdrowotne młodzieży szkolnej w Polsce na tle wybranych uwarunkowań socjodemograficznych. Wyniki Badań HBSC 2014, red. J. Mazur, Instytut Matki i Dziecka, Warszawa 2015.

Erikson E.H., Dzieciństwo i społeczeństwo, Dom Wydawniczy Rebis, Poznań 1997.

Essau C.A., Hutchinson D., Alcohol use, abuse and dependence, [w:] Adolescent addiction: epidemiology, assessment and treatment, red. C.A. Essau, Academic Press Elsevier, London 2008.

Flores P.J., Addiction as an attachment disorder, Jason Aronson Books, Lanham 2004. 
Grzegorek A., Co psycholog może mieć na myśli, kiedy mówi o tożsamości? [w:] Wkręgu psychologicznej problematyki tożsamości, red. D. Kubacka-Jasiecka, M. Kuleta, Wydawnictwo Uniwersytetu Jagiellońskiego, Kraków 2008.

Grzegorzewska I., Pisula E., Borkowska A.R., Psychologia kliniczna dzieci i młodzieży, [w:] Psychologia kliniczna, red. L. Cierpiałkowska, H. Sęk, Wydawnictwo Naukowe PWN, Warszawa 2016.

Gullotta T.P., A Selected Social History of the Stepping-Stone Drugs, [w:] Adolescent Substance Abuse Evidence-Based Approaches to Prevention and Treatment, red. C.G. Leukefeld, T.P. Gullotta, M. Staton-Tindall, Springer Science+Business Media, New York 2009.

Hardy S.A., Francis S.W., Zamboanga B.L., Kim S.Y., Anderson S.S.G., Forthun L.F., The roles of identity formation and moral identity in college student mental health, health-risk behaviors, and psychological well-being, Journal of Clinical Psychology, 2013, 69(4).

Hejmanowski Sz., Okres dorastania - zagrożenia rozwoju, Remedium, 2004, 1(131).

Hibell B., Guttormsson U., Ahlström S., Balakireva O., Bjarnason T., Kokkevi A., Kraus L., The 2011 ESPAD report. Substance use among students in 36 European countries, Szwedzka Rada ds. Informacji o Alkoholu i Innych Używkach, Sztokholm 2012.

Höfler D.Z., Kooyman M., Attachment transition, addiction and therapeutic bonding - an integrative approach, Journal of Substance Abuse Treatment, 1996, 13(6).

Holmes J., Attachment theory and psychoanalysis: a rapprochement, British Journal of Psychotherapy, 2000, 17(2).

Huflejt-Łukasik M., Ja i procesy samoregulacji: różnice między zdrowiem a zaburzeniami psychicznymi, Wydawnictwo Naukowe Scholar, Warszawa 2010.

Jankowiak B., Zachowania ryzykowne młodzieży. Studium teoretyczno-empiryczne, Wydawnictwo Naukowe UAM, Poznań 2017.

Jarymowicz M., Psychologia tożsamości, [w:] Psychologia. Podręcznik akademicki, tom 3 - Jednostka w społeczeństwie i elementy psychologii stosowanej, red. J. Strelau, Gdańskie Wydawnictwo Psychologiczne, Gdańsk 2002.

Jessor R., Risk Behavior in Adolescence: A Psychosocial Framework for Understanding and Action, Journal of Adolescent Health, 1991, 12.

Jones D.B., Addiction and pathological accommodation: an intersubjective look an impediments to the utilization of Alcoholics Anonymous, The International Journal of Psychoanalytic Self Psychology, 2009, 4.

Khantzian E.J., Treating addiction as a human process, Jason Aronson Books, Lanham 2007.

Khantzian E.J., Albanese M., Understanding addiction as self-medication. Finding hope behind the pain, Rowman \& Littlefield Publishers, Lanham 2008.

Kohut H., Preface, [w:] Psychodynamics of drug dependence. NIDA Research Monograph 12, red. J.D. Blaine, D.A. Julius, Superintendent of Documents, U.S. Government Printing Office, Washington 1977.

Kubacka-Jasiecka D., Autodestruktywna tożsamość a kryzys emocjonalny, [w:] W kręgu psychologicznej problematyki tożsamości, red. D. Kubacka-Jasiecka, M. Kuleta, Wydawnictwo Uniwersytetu Jagiellońskiego, Kraków 2008.

Kubacka-Jasiecka D., Kuleta M., Wprowadzenie, [w:] W kręgu psychologicznej problematyki tożsamości, red. D. Kubacka-Jasiecka, M. Kuleta, Wydawnictwo Uniwersytetu Jagiellońskiego, Kraków 2008.

Kueppenbender K., Herman J., Khantzian E., Albanese M., "Narcotics helped, I thought." Recurrent traumatization and recovery from drug dependence, Harvard Review of Psychiatry, 2008, 16.

Laing R.D., Podzielone "ja". Egzystencjalistyczne studium zdrowia i choroby psychicznej, Dom Wydawniczy Rebis, Poznań 1999. 
Levin J.D., Treatment of alcoholism and other addictions. A self-psychology approach, Jason Aronson Inc Northvale, New Jersey - London 1991.

Mandrosz-Wróblewska J., Strategie redukowania problemów tożsamościowych: różnicowanie "Ja - My" i "My - Oni", [w:] Studia nad spostrzeganiem relacji Ja - Inni: tożsamość, indywiduacja - przynależność, red. M. Jarymowicz, Ossolineum, Wrocław 1988.

Marcia J.E., Development and Validation of Ego - Identity Status, Journal of Personality and Social Psychology, 1966, 3(5).

Mazur J. (red.), Zdrowie i zachowania zdrowotne młodzieży szkolnej w Polsce na tle wybranych uwarunkowań socjodemograficznych. Wyniki Badań HBSC 2014, Instytut Matki i Dziecka, Warszawa 2015.

Morgenstern J., Leeds J., Contemporary psychoanalytic theories of substance abuse: a disorder in search of a paradigm, Psychotherapy, 1993, 30(2).

Obuchowska I., Adolescencja, [w:] Psychologia rozwoju człowieka. Charakterystyka okresów życia człowieka, t. 2, red. B. Harwas-Napierała, J. Trempała, Wydawnictwo Naukowe UAM, Warszawa 2005.

Oleś P., Psychologia człowieka dorosłego, Wydawnictwo Naukowe PWN, Warszawa 2011.

Ostaszewski K., Zapobieganie używaniu substancji psychoaktywnych, [w:] Edukacja zdrowotna, red. B. Woynarowska, Wydawnictwo Naukowe PWN, Warszawa 2013.

Padykula N.L., Conklin P., The self regulation model of attachment trauma and addiction, Clinical Social Work Journal, 2010, 38(4).

Pawliczuk W., Poradnictwo psychologiczne w okresie adolescencji, [w] Poradnictwo psychologiczne, red. Cz. Czabała, S. Kluczyńska, Wydawnictwo Naukowe PWN, Warszawa 2015.

Pilarska A., Ja i tożsamość a dobrostan psychiczny, Wydawnictwo Naukowe WNS UAM, Poznań 2012.

Read A., Psychotherapy with addicted people, [w:] The psychodynamics of addiction, red. M. Weegmann, R. Cohen, Whurr Publishers, London - Philadelphia 2006.

Robertson E.B., Perl H.I., Reider E.E., Sims B.E., Crump A.D., Compton W.M., Drug use prevention: definitions and terminology, [w:] Handbook of Adolescent Drug Use Prevention: Research, Intervention Strategies, and Practice, red. L.M. Scheier, American Psychological Association 2015.

Sachs K.S., Treating alcoholism as a disorder of the self: insights from alcoholics anonymous, Alcoholism Treatment Quarterly, 2003, 21(2).

Schwartz S., The Evolution of Eriksonian and Neo-Eriksonian Identity Theory and Research: a Review and Integration, Identity: An International Journal of Theory and Research, 2001, $1(1)$.

Schwartz S.J., Forthun L.F., Ravert R.D., Zamboanga B.L., Umaña-Taylor A.J., Filton B.J., Kim S.Y., Rodriguez L., Weisskirch R.S., Vernon M., Shneyderman Y., Williams M.K., Agocha V.B., Hudson M., Identity consolidation and health risk behaviors in college students, American Journal of Health Behavior, 2010, 34(2).

Sęk H., Kaczmarek Ł.D., Promocja zdrowia i prewencja zaburzen, [w:] Psychologia kliniczna, red. L. Cierpiałkowska, H. Sęk, Wydawnictwo Naukowe PWN, Warszawa 2016.

Sikora K., Tożsamość jako przedmiot badań psychologii, [w:] W kregu psychologicznej problematyki tożsamości, red. D. Kubacka-Jasiecka, M. Kuleta, Wydawnictwo Uniwersytetu Jagiellońskiego, Kraków 2008.

Sokolik M., Psychoanaliza i Ja: kliniczna problematyka poczucia tożsamości, Jacek Santorski \& CO Agencja Wydawnicza, Warszawa 2000.

Thorberg F.A., Lyvers M., Attachment, fear of intimacy and differentiation of self among clients in substance disorder treatment facilities, Addictive Behaviors, 2006, 31(4).

Weegmann M., Khantzian E.J., Envelopments: immersion in and emergence from drug misuse, American Journal of Psychotherapy, 2011, 65(2). 